\title{
CONGRESSIONAL MEDALS OF HONOR AND IOWA SOLDIERS.
}

\author{
BY COL, CHARLES A. CLARK.
}

The War Department has recently issued a roster of the holders of Congressional Medals of Honor up to and including September 1, 1904. It is a book of one hundred fifty-three pages, and shows the name of every soldier to whom a Medal of Honor has been issued, the battle, skirmish, or affair in which it was won, with the date and the ground of award.

These medals were authorized by Congress in 1862 and ' 63. By a later Act the Secretary of War was authorized to design and issue a rosette or knot to be worn in the buttonhole in place of the medal itself. Pursuant to this Act, the Secretary prescribed a knot of narrow silk ribbon, in the national colors, red, white and blue, to accompany the medal. This little knot is occasionally seen in the buttonhole of some old soldier, but not many of our people recognize it as a national decoration which is the equivalent of the Cross of the Legion of Honor established by the great Napoleon of France.

The last Congress passed an Act authorizing the striking of medals of a new design for which the original bronze medals may be exchanged, at the option of those who hold them. The same act authorized a new rosette or knot of a more distinctive type than that now worn.

The War Department has adopted a design for the new Medals of Honor. They will be ready for issue during the present month. The new medal, like the old, will be of bronze. The base will be a circular disc. Upon that will rest an enameled laurel wreath, and, resting on the enameled wreath will appear the original five-pointed star which constituted the first Medal of Honor. In the center of the star will be a raised head of Minerva, around which will be the inscription in block letters, "United States of America". The medal will be suspended from a bronze bar bearing the 
word "Valor". Above the bar, and grasping it, will be a bronze eagle. This will be suspended from a light blue silk ribbon bearing thirteen white stars for the original American colonies, and attached to the clasp to be pinned to the coat.

The new rosette will consist of a raised six-sided medallion covered with light blue silk ribbon, upon which will also appear thirteen white stars. This emblem when worn in the buttonhole will not be mistaken for any other now in use.

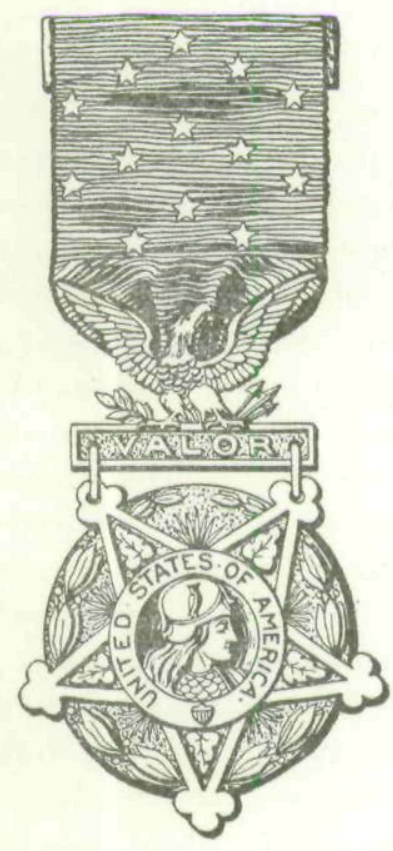

NEW ARMY MEDAL OF HONOR.

FULL SIZE.

The rules governing the issuance of these medals call for special acts of valor in which the soldier or officer not only has distinguished himself by marked bravery, but has also acted upon his own initiative, as contradistinguished from merely performing his duty, or acting in obedience to orders. It was for this reason that Colonel Roosevelt as Commandant of the Rough Riders was unable, as he very much desired, 
to receive a Medal of Honor for his charge at San Juan Hill. He was told that he simply performed his duty as all officers and all soldiers were bound to do, and that a Medal of Honor was not awarded in cases of this character.

The Medals of Honor when issued by the War Department bear inscriptions in the following form:

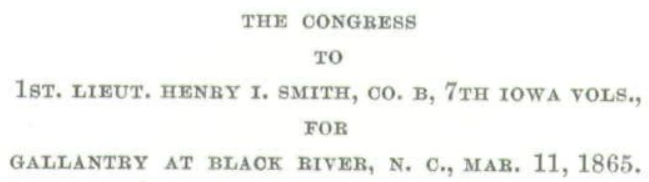

It appears from the official roster of Medals of Honor above referred to, that the total number of medals issued for acts of valor in the field up to the first day of last September, was 1,551. Of these 493 were issued to the scouts and the regular army of the United States, and several were issued in the Spanish war, and for service in the Philippines, leaving about 1,000 issued to the volunteers of the Civil War. The proportion issued to the regular army seems large, but it should be remembered that the medals are still being issued up to the present time, and that many have been issued to the regulars for Indian fighting of the most daring and desperate character. Besides this, regular officers have already had a higher appreciation of the real meaning of the Medal of Honor, and have been more careful in the official reports, upon which the issuance of medals is founded, to report instances of gallantry and daring among their officers and men, than the officers of volunteer regiments were accustomed to do during the war of the Rebellion. If proper attention had been given to the matter by volunteer officers, along the fifteen hundred miles of firing line during the four years of the Civil War, there would have been vastly more numerous distributions of the decoration among officers and men of the volunteer service. Probably the Eighth U. S. Cavalry (regulars) has received more Medals of Honor than any other one regiment. 

list.

Many interesting matters appear in the Medal of Honor

In at least one instance a medal was awarded to a gallant soldier who never lived to receive it. It can easily be imagined with what reverence it will be treasured by his relatives, and what a sacred heirloom it will be in his family.

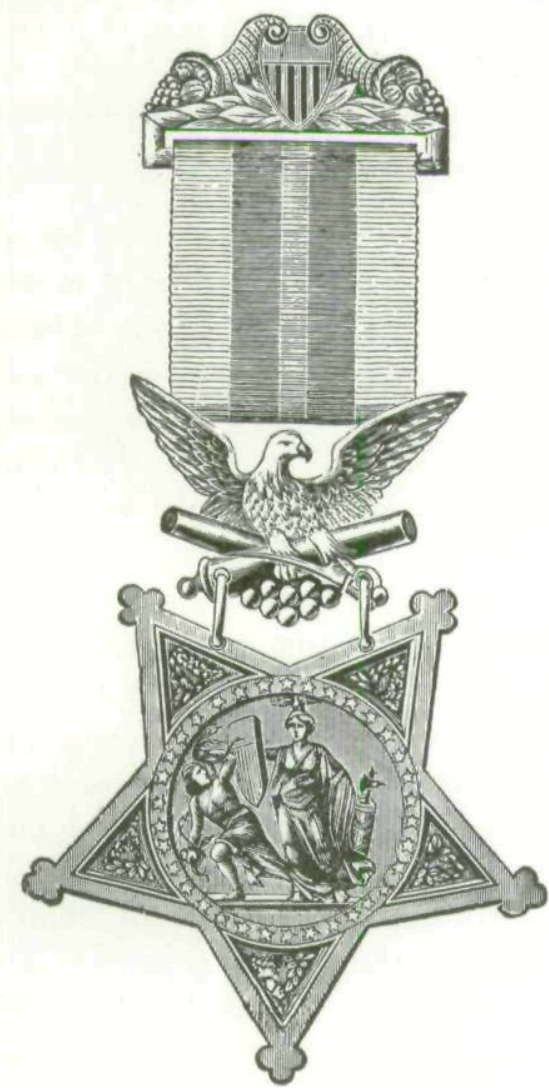

ORIGINAL PATTERN ARMY MEDAL OF HONOR.

Here is the record:

FULL BIZE.

Gasson, RiCHARD, Sergt., Co. K, 47th N. Y. Inf. Chapin's Farm, Va. Sept.

29, 1864. Fell dead while planting the colors of his regiment on the enemy's works.

Dr. Mary E. Walker, now deceased, who for so many years wore man's attire about Washington, is the one woman 
who received the Medal of Honor. She earned it in the field, in battles of the Army of the Potomac, and in service with General Sherman's armies in the west. She was on one occasion held up by the notorious bushwhacker, Champ Ferguson, but escaped by her coolness and presence of mind. She was captured by the Confederates and held a prisoner at Castle Thunder, Richmond, for four months. At that time she was a regularly commissioned assistant surgeon of the regular army. She was finally exchanged for Dr. Lightfoot of Tennessee, a surgeon in the Confederate service.

Old soldiers are disposed to look upon the military exploits of the drummer boy as somewhat mythical. Here, however, is a historical example taken from the roster.

Howe, Orion P. Mus., Co. C, 55th Ill. Inf. Vicksburg, Miss. May 19, 1863. A drummer boy, 14 years of age, severely wounded and exposed to a heavy fire from the enemy, he persistently remained upon the field of battle until he had reported to Gen. W. T. Sherman the necessity of supplying cartridges for the troops under command of Colonel Malmborg.

And here is the manner in which another mere lad earned his medal:

Gwyne, Nathaniel MoLean, Priv., Co. H, 13th Ohio Cav. Petersburg, Va. July 30,1864 . When about entering upon the charge, this soldier, then but 15 years old, was cautioned not to go in, as he had not been mustered. He indignantly protested and participated in the charge, his left arm being crushed by a shell and amputated soon afterwards.

Four other drummer boys earned the Medal of Honor by their heroic acts:

WM. H. Horsfalu, Drummer, Co. G, 1st Ky. Inf., saved the life of a wounded officer lying between the lines of battle.

Julius Langbein, Co. B, 9th N. Y. Inf., a drummer boy of fifteen, volunteered, under heavy fire, to go to the aid of a wounded officer, and rescued him from a most perilous situation.

Benjamin Levex, Co. G, 1st N. Y. Inf., a drummer boy, went into battle at Glendale, Va., with the musket of a sick comrade, and saved the colors of his regiment from capture when the color guard were shot down.

William Magee, a drummer boy of Company C, 33rd N. J. Inf. in a charge at Murfreesboro was among the first to reach the field battery of the enemy, and mounting the artillery horses brought the guns into the Union lines. 
Iowa has her drummer boy hero also. Long after the War of the Rebellion, in 1900, in the relief expedition to Peking to deliver the American and other legations from the bloodthirsty Boxers, Calvin Pearl Titus, a native of Vinton, Iowa, enlisted as a musician, was the first to scale the walls of the sacred city and plant the American flag upon them. For this gallant and perilous exploit he was awarded a Medal of Honor. He returned to Vinton and was given a public reception July 4, 1900, and was then appointed cadet at West Point, where he has made a highly creditable record. He has now graduated, number 43 in a very large class, his standing being relatively as high as many of our most distinguished officers and generals. Iowa will watch his future career with the utmost interest and may well anticipate for him a record of great efficiency and valor as an officer in the regular army.

The following is his record as it appears in the official roster:

Trtus, Calvin Pearl, Mus., Co. E, 14th U. S. Inf. Peking, China. Apr. 14, 1900. Gallant and daring conduct in the presence of his colonel and other officers and enlisted men of his regiment; was first to scale the wall of the city.

There were also "fighting parsons" in the Union forces during the Civil War. Chaplains Francis B. Hall, 16th N. Y. Inf.; Milton L. Haney, 55th Ill. Inf.; and John M. Whitehead, 15th Ind. Inf,, were all awarded medals for most distinguished bravery and efficiency on the field of battle.

Lieut. James Hill, 21st Iowa Inf., seems to have combined the church militant with gallant soldierly fighting. He was a clergyman before the war, and after the act of gallantry for which he received the Medal of Honor he was assigned to duty as chaplain of his regiment.

Wm. F. Cody as guide for the Regulars in their Indian campaigns was given a medal for "gallantry in action".

Quite a number of medals have been awarded to Indian scouts: Pompey Factor, Sergeant Jim, Kosoha Machol, Rowdy, and others. 
One civilian, a Mr. Docier, was given a medal for "gallantry in action and on the march during an Indian campaign in 1870 while serving as citizen guide".

In numerous and notable instances medals were awarded to non-commissioned officers and privates of the colored troops during the Civil War.

General Funston was awarded a medal of honor as Colonel of the 20th Kansas Infantry-not for the capture of Aguinaldo-but for gallantry and daring in crossing a difficult river and dislodging the Filipinos from their entrenchments.

Senator Quay of Pennsylvania received his medal for services at Burnside's battle of Fredericksburg, December 13th, 1862, on the following record: "Although out of service he voluntarily resumed duty on the eve of battle and took a conspicuous part in the charge on the Heights".

Major J. B. Pond who so long managed the American lecture bureau was decorated for gallantry in a fight with guerrillas at Baxter Springs, Kansas, October 6th, 1863.

General Horace Porter, our present Minister to France, was given a medal for his services as a volunteer aide at Chickamaugua. He was then a captain of the ordnance department; he rallied fugitives and held the broken Union lines under heavy fire, thus saving batteries and wagon-trains.

General Nelson A. Miles perhaps wears his medal more proudly than the insignia of his rank as Lieutenant General. It was awarded him for services while Colonel of the 61 st $\mathrm{N}$. Y. Volunteers, at the battle of Chancellorsville, where he was severely wounded.

Major-General Daniel E. Sickles received a medal for his historic fight at the Bloody Angle on the second day of the battle of Gettysburg. He once in after years said to General Longstreet whom he fought there, "Longstreet, it was very mean of you to knock off my leg at Gettysburg". General Longstreet replied: "I did not intend to leave you a leg to stand on". 
Major-General John M. Scofield was also decorated for his services as Major of the 1st Missouri Volunteers at the battle of Wilson's Creek, Mo., August 10th, 1861.

Major-General O. O. Howard received the medal for the battle of Fair Oaks, Va., June 1st, 1862, where heled a New York regiment of his brigade into action, and lost his right arm as he cheered them on.

General John C. Black, then Lieutenant Colonel, 37th Illinois Volunteers, received a medal for gallantry at Prairie Grove, Arkansas, December 7th, 1862, where he led a charge of his regiment and captured a Confederate battery, and where he was severely wounded in both arms.

General Llewellyn G. Estes, recently deceased, then Captain and Assistant Adjutant General, received a medal for bravery at Flint River, Ga., August 30th, 1864, where he volunteered to lead a desperate and successful charge over a burning bridge.

These six generals last mentioned have been successively commanders in chief of the "Medal of Honor Legion", a national society maintained by medal of honor men, which, like the Grand Army of the Republic and the Loyal Legion, holds an annual encampment or reunion. These annual meetings of the Medal of Honor Legion have been held in the east up to the present time, but it is hoped that they may be held west of Chicago at no distant day.

Of the 1,000 medals issued to the volunteer forces in the field, Iowa received 27, her full share in proportion to the millions who fought for the Union during the Civil War. It is remarkable that a large portion of these Iowa medals-noless than 14 out of the 27 -were awarded for the capture of Confederate flags. The list reads as though wherever a Confederate flag was displayed in front of Iowa troops, some Iowa soldier marked it for his own, and triumphantly brought it in.

The following is the Iowa list in full, with the date, engagement, and act, for which the medal was awarded in each instance. 
Bates, Norman F. Sergt., Co. E, 4th Iowa Cav. Columbus, Ga. Apr. 16, 1865. Capture of flag and bearer.

Bebs, Enward J. Priv., Co. D, 4th Iowa Cav. Columbus, Ga. Apr. 16, 1865. Capture of flag.

Brrdsald, Horatio L. Sergt., Co. B, 3rd Iowa Cav. Columbus, Ga. Apr. 16, 1865. Capture of flag and bearer.

Boquet, Nroholas. Priv., Co. D, 1st Iowa Inf. Wilson's Creek, Mo. Aug. 10, 1861. Voluntarily left the line of battle, and exposing himself to imminent danger from a heavy fire of the enemy, assisted in eapturing a riderless horse at large between the lines, and hitching him to a disabled gun, saved the gun from capture.

Bras, Edgar A. Sergt., Co. K, 8th Iowa Inf. Spanish Fort, Ala. Apr. 8, 1865. Capture of flag.

Cosgrtyf, Richard H. Priv., Co. L, 4th Iowa Cav. Columbus, Ga. Apr. 16,1865 . Capture of flag in a personal encounter with its bearer.

Dunlavy, James. Priv., Co. D, 3rd Iowa Cav. Osage, Kas. Oct. 25, 1864. Gallantry in capturing General Marmaduke.

Elson, JAmes M. Sergt., Co. C, 9th Iowa Inf. Vicksburg, Miss. May 22, 1863. Carried the colors in advance of his regiment and was shot down while attempting to plant them on the enemy's works.

Fanning, Nicholas. Priv., Co. B, 4th Iowa Cav. Selma, Ala. Apr. 2, 1865. Capture of Confederate States silk flag and two staff officers.

Goduex, Leonidas M. 1st Sergt., Co. E, 22d Iowa Inf. Vicksburg, Miss. May 22, 1863. Led his company in the assault on the enemy's works and gained the parapet, there receiving three very severe wounds. He lay all day in the sun, was taken prisoner, and had his leg amputated without anaesthetics.

Hays, John H. Priv., Co. F, 4th Iowa Cav. Columbus, Ga. Apr. 16, 1865. Capture of flag and bearer, Austin's Battery (C. S. A.).

Healey, George W. Priv., Co. E, 5th Iowa Cav. Newman, Ga. July 29, 1864. Although nearly surrounded by the enemy, captured a Confederate soldier, and with the aid of a comrade who joined him later, captured four other Confederates, disarmed the five, and brought them all into the Union lines.

Herrington, Prty B. Priv., Co. E, 11th Iowa Inf. Near Kenesaw Mountain, Ga. June 15, 1864. With one companion and under a fierce fire from the enemy at close range, went to the rescue of a wounded comrade who had fallen between the lines and carried him to a place of safety.

Herron, Franors J. Lieut. Col., 9th Iowa Inf. Pea Ridge, Ark. Mar. 7, 1862. Was foremost in leading his men, rallying them to repeated acts of daring, until himself disabled and taken prisoner.

HiLl, JAs. 1st Lient., Co. I, 21st Iowa Inf. Champion Hill, Miss. May 16, 1863. By skillful and brave management captured three of the enemy's pickets. 
Kaltenbach, Luther. Corp., Co. F, 12th Iowa Inf. Nashville, Tenn. Dec. 16, 1864. Capture of flag, supposed to be of 5th Mississippi Infantry (C. S. A.).

Max, Wruliam. Priv., Co. H, 32d Iowa Inf. Nashville, Tenn. Dec. 16, 1864. Ran ahead of his regiment over the enemy's works and captured from its bearer the flag of Bonanchad's Confederate battery.

Mayes, Wilutam B. Priv., Co. K, 11th Iowa Inf. Near Kenesaw Mt., Ga. June 15,1864 . With one companion, under a fierce fire from the enemy at close range, went to the rescue of a wounded comrade who had fallen between the lines, and earried him to a place of safety.

Mrmeer, James P. Priv., Co. D, 4th Iowa Cav. Selma, Ala. Apr. 2, 1865. Capture of flag.

Morgan, Rtohard H. Corp., Co. A, 4th Iowa Cav. Columbus, Ga. Apr. 16, 1865. Capture of flag inside the enemy's works, contesting for its possession with the bearer.

Power, Albert. Priv., Co. A, 3rd Iowa Cav. Pea Ridge, Ark. Mar. 7, 1862. Under a heavy fire and at great personal peril went to the aid of a dismounted comrade who was surrounded by the enemy, took the man up behind him on the horse and carried him to a place of safety.

Slonn, Andrew J. Priv., Co. H, 12th Iowa Inf. Nashville, Tenn. Dec.16, 1864. Capture of flag.

Smrth, Henry I. 1st Lieut., Co. B, 7th Iowa, Inf. Black River, N. C. Mar. 15, 1865. Voluntarily, and under fire, rescued a comrade from death by drowning.

Swan, Charles A. Priv., Co. K, 4th Iowa Cav. Selma, Ala. Apr. 2, 1865. Capture of flag (supposed to be the 11th Mississippi) and bearer.

Trberts, Andrew W. Priv., Co. I, 3rd Iowa Cav. Columbus, Ga. Apr. 16, 1865. Capture of flag and bearer, Austin's Battery (C. S. A..)

Twombly, Voltarke P. Corp., Co. F, 2d Iowa Inf. Ft. Donelson, Tenn. Feb. 15, 1862. Took the colors after three of the color guard had fallen, and although almost instantly knocked down by a spent ball, immediately arose and bore the colors to the end of the engagement.

Wrulramson, James A. Col., 4th Iowa Inf. Chickasaw Bayou, Miss. Dec. 29,1862 . Led his regiment against a superior force, strongly entrenched, and held his ground when all support had been withdrawn.

Young, Caltakx M. Sergt., Co. L, 3rd Iowa Cav. Osage, Kas. Oct. 25, 1864. Gallantry in capturing General Cabell.

It need hardly be said that the official record set forth above is in every case a mere skeleton, and gives no adequate idea of the real acts of desperate bravery and gallantry for which medals have been awarded. 
A history of Medal of Honor men has been compiled in two large octavo volumes by the Perrien-Keydel Company, Detroit, Mich., with an introduction by General H. M. Duffield. By permission of this firm, and to illustrate the deeds for which medals of honor are issued, the following account of the exploit of Private James Dunlavy of the 3rd Iowa Infantry, is transferred from that work to this article. The man who captured General Marmaduke in the face of a brigade of Confederate troopers is well worthy of having his gallant action set forth at length.

\section{* CAPTURE OF GENERAL MARMADUKE.}

The capture of a general officer in battle is a noteworthy event, but when the officer is one of prominence the act becomes of great interest, and especially when the capture is made single-handed by a private soldier; thus the capture of Confederate General Marmaduke by private James Dunlavy, Company D, Third Iowa Cavalry, necessarily takes a high place in the annals of history.

Amid the heavy roar of cannon, on the open plains of Kansas, the two contending forces met to do battle for supremacy at Little Osage Crossing on the morning of the 25th of October, 1864. The Confederate artillery was playing upon the Federal forces with fearful effect, but notwithstanding this incessant and terrific fire the Federal infantry never wavered. The safety of the Federals lay in a charge by which the enemy's guns could be captured. The movement was begun slowly at first, but increased in velocity until it swept on resistless as an avalanche. The crash of mus. ketry, the scream of shell, the buzzing of canister and ball enthused the dashing cavalry. The charge was successful, the rebels being routed. At this juncture Private James Dunlavy was severely wounded, his arm being shattered by a piece of shell, which also struck his horse, making him wheel suddenly to the rear. Undaunted the plucky rider headed him in the direction of a brigade which he thought was his own, but which proved to be the enemy. He noticed a Confederate officer riding among the excited soldiers and exhorting them to make a stand. Dunlavy raised his carbine, aimed at him and fired. The shot missed its mark, but had served to attract the officer's attention to the doughty soldier, and dashing up to him he asked in an angry tone: "What do you mean, shooting at your own officer?" "Give me that revolver! Surrender, or I'll fire!" To say that the Confederate officer was paralyzed with surprise at finding himself at the mercy of a Union soldier is expressing it mildly. But he offered no resistance and handed over his revolver. Just then a comrade ran up to Dunlavy. "My horse has been shot. Give me that of your prisoner," he said.

"Deeds of Valor, vol, 1, pp. 450-52. 
Dunlavy made the officer d'smount and accommodated his comrade. Then the two started for the rear, Dunlavy on horseback, the prisoner trotting along at double-quick.

The latter was far from relishing the hurried march and soon asked for a slower tempo. "I am very tired and worn out. Have been up all night," he said.

Good naturedly the eavalryman slowed down. The Confederate made still another request.

"Can't you get me a horse? I'd like to ride."

But Dunlavy was not inclined to make further concessions. Why should I give him a horse? he thought. And his reply to the question was a curt "No".

Again the silence was broken by the prisoner.

"Will you take me to General Pleasanton?" he said. "I am personally acquainted with him". Becoming more confidential, he added: "Young man, I'll tell you who I am".

He had not quite finished the sentence when Colonel C. W. Blair, of General Curtis' staff, rode up and approached the prisoner.

"I am General Marmaduke", the officer said, addressing the new-comer.

It was now Private Dunlavy's turn to be surprised. He apologized to his distinguished prisoner and with all the politeness at his disposal turned him over to Colonel Blair, who procured a horse for General Marmaduke and brought both prisoner and captor before General Curtis, who complimented Dunlavy and ordered him to the hospital.

It will be observed that the rank of the officer or soldier at the time the medal was issued is preserved on the official roster. Thus Colonels Herron and Williamson afterwards. became distinguished general officers, and there were no doubt numerous other promotions among the Iowa holders of medals of honor, but the writer is unable to state them except in the case of Corporal V. P. Twombly who was afterwards promoted to Captain, Second Iowa Infantry.

This article is designed especially to put on record in the historical archives of Iowa the names of Iowa officers and soldiers to whom medals have been awarded. It may not be out of place, however, to give the names and records of the following who have long been citizens of Iowa:

Russels, Mruton, now of Des Moines, Iowa. Captain Co. A, 51st Ind. Inf. Stone River, Tenn. Dec.29, 1862. Was the first man to cross Stone river, and in the face of a galling fire from the concealed skirmishers of the enemy, led his men up the hillside, driving the opposing. skirmishers before them.

VoL. VII-8. 
Russerl, Charles L., now an inmate of Soldiers' Home, Marshalltown, Iowa. Corporal Co. H, 93rd N. Y. Inf. Spottsylvania, Va. May 12, 1864. Capture of flag of 4 th Virginia Infantry (C. S. A.).

Cadwell, Luman L., Sergt., Co. B, 2d N. Y. Vet. Cav., now of Decorah, Iowa. Alabama Bayou, La., Sept. 20, 1864. Swam the bayou under fire of the enemy and captured and brought off a boat by means of which the command crossed and routed the enemy.

Clark, Chas. A., now of Cedar Rapids, Iowa. Lieutenant and Adjutant, 6th Me. Inf. Brooks Ford, Va. May 4, 1863. Having voluntarily taken command of his regiment in the absence of its commander, at great personal risk and with remarkable presence of mind and fertility of resource led the command down an exceedingly precipitous embankment to the Rappahannoci river, and by his gallantry, coolness and good judgment in the face of the enemy saved the command from capture or destruction.

- General L. A. Grant, afterwards Secretary of War, resided at Des Moines for several years and was the original proprietor of a small town west of Des Moines on the Rock Island railroad. His record is as Iollows: Colonel 5th Vt. Inf. Salem Heights. May 3, 1363. Personal gallantry and intrepidity displayed in the management of his brigade and in leading it in the assault, in which he was wounded.

To this list should be added Major George R. Burnett, 9th U. S. Cav., now detailed as Militant Commandant of the State University at Iowa City.

His record is as follows:

Burnetr, George R., 2d Lieut., 9th U. S. Cav., Cuchillo Negro Mountains, N. Mex., Aug. 16,1881. Saved the life of a dismounted soldier, who was in imminent danger of being cut off, by alone galloping quickly to his assistance under a heavy fire and escorting him to a place of safety, his horse being shot twice in this action.

It would be interesting to know the personal history of each of the Medal of Honor men from Iowa in civil life since the war, and it is to be hoped that details may be furnished The Annals which will enable it to complete the record of this heroic group of Iowa soldiers and citizens.

Cedar Rapids, Iowa, June 1, 1905. 
Copyright of Annals of Iowa is the property of State of Iowa, by \& through the State Historical Society of Iowa and its content may not be copied or emailed to multiple sites or posted to a listserv without the copyright holder's express written permission. However, users may print, download, or email articles for individual use. 